\title{
İnfertil Bireylerin Kaygı Düzeyleri, Sosyal Destek Algısı ve Evlilik Uyumunun İncelenmesi
}

\section{An Investigation of Infertile Individuals' Anxiety Levels, Social Support Perceptions, and Marital Adjustment}

\begin{abstract}
Ayşe Şenoğlu* ${ }^{1}$, Sultan Alan ${ }^{2}$
ABSTRACT

Background: Infertility is a process that brings with it medical, psychological and social problems and has cultural, religious and class aspects. This study aims to investigate infertile individuals' anxiety levels, social support perceptions, and marital adjustment. Methods: This study descriptive was conducted in the infertility polyclinic of a test tube baby center of a private hospital and the infertility polyclinic of a university hospital in Turkey between October and April 2017. The sample of the study was 261 infertile individuals, 184 females and 77 males, who agreed to participate in the study. Collected through the question form, State-Trait Anxiety Inventory (STAI I-II), Multidimensional Scale of Perceived Social Support (MSPSS), and Marriage Adjustment Scale (MAS). Data were analyzed in SPSS package program using numbers, percentage distributions, mean, standard deviation, Independent Sample t test, ANOVA, Mann-Whitney U, Kruskal-Wallis H and Spearman Correlation tests. Results: The results showed that the participants State Anxiety Inventory total score average was 38.62 \pm 11.64 , Trait Anxiety Inventory total score average was 43.51 \pm 8.96 ; MSPSS total score average was 54.23 \pm 20.99 ; The mean total score average was of MAS was found to be $46.42 \pm 8.92$. In the study, it was determined that there was a negative statistically significant relationship between the STAI I-II total score averages and the MSPSS total score averages and the total mean scores on MAS $(\mathrm{rs}=-0.151, \mathrm{p}=0.014 ; \mathrm{rs}=-0.223$, $\mathrm{p}=0.000)$. A statistically significant difference was found in terms of education, employment and income level of the participants, as well as STAI I-II total score averages and MSPSS total score averages $(\mathrm{p}<0.05)$. The fact that the participants work in an income-generating job, have high education and income levels reduces their anxiety levels and increases the perception of social support. Conclusion: According to the average score obtained from the scales, the participants were moderately anxious, had a perception of social support above the moderate level, and according to the total score averages of the MAS, $75.5 \%$ of the participants were found to have a compatible marriage. The fact that individuals work in an income-generating job, have high education and income levels reduces their anxiety levels and increases their perceptions of social support. As the anxiety levels of individuals increase, the perception of social support and marital adjustment decrease.
\end{abstract}

Key words: Infertility, anxiety, social support, marital adjustment.

\section{ÖZET}

Giriș: İnfertilite tıbbi, psikolojik ve sosyal sorunları beraberinde getiren, kültürel, dinsel ve sınıfsal yönleri olan bir süreçtir. Bu araştırma, infertil bireylerin kaygı düzeylerinin, sosyal destek algılarının ve evlilik uyumlarının incelenmesi amacıyla yapılmışır. Yöntem: Araştırma, Ekim-Nisan 2017 tarihleri arasında, Türkiye'de özel bir hastanenin tüp bebek merkezi ile bir üniversite hastanesinin infertilite polikliniğinde tanımlayıcı nitelikte yürütülmüştür. Araştırmanın örneklemini, araştırmaya katılmayı kabul eden 184 kadın ve 77 erkek olmak üzere toplam 261 infertil birey oluşturmuştur. Veriler, soru formu, Durumluk-Sürekli Kaygı Ölçeği (STAI I-II), Çok Boyutlu Algılanan Sosyal Destek Ölçeği (ÇBASDÖ) ve Evlilikte Uyum Ölçeği (EUÖ) formları kullanılarak elde edilmiştir. Elde edilen verilerin analizleri SPSS programı ile sayı, yüzde dağılımları, ortalama, standart sapma, Bağımsız Gruplarda $t$ testi, ANOVA, Mann-Whitney U, Kruskal-Wallis H ve Spearman Korelasyon testleri kullanılarak yapılmıştır. Bulgular: Katılımcıların Durumluk Kaygı Ölçeği

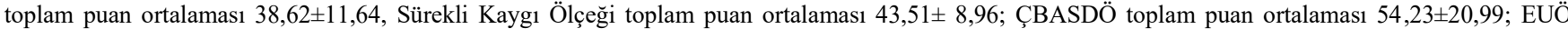
toplam puan ortalaması 46,42 $\pm 8,92$ olarak bulunmuştur. Araştırmada STAI I-II toplam puan ortalamaları ile ÇBASDÖ toplam puan ortalamaları ve EUÖ toplam puan ortalamaları arasında negatif yönlü istatistiksel açıdan anlamlı bir ilişki olduğu saptanmıştır $\left(\mathrm{r}_{\mathrm{s}}=-0,151, \mathrm{p}=0,014 ; \mathrm{r}_{\mathrm{s}}=-0,223, \mathrm{p}=0,000\right)$. Katılımcıların eğitim durumu, çalışma durumu ve gelir düzeyi ile STAI I-II toplam puan ortalamaları ve ÇBASDÖ toplam puan ortalamaları açısından istatistiksel olarak anlamlı farklılık tespit edilmiștir $(\mathrm{p}<0,05)$. Katılımcıların gelir getiren bir iște çalışmaları, eğitim ve gelir düzeylerinin yüksek olması kaygı düzeylerini azaltmakta, sosyal destek algısını artırmaktadır. Sonuç: Ölçeklerden elde edilen puan ortalamalarına göre katılımcılar orta düzeyde kaygılı, orta düzeyin üzerinde sosyal destek algısına sahip ve EUÖ toplam puan ortalamalarına göre katılımcıların \% 75,5 'nin evlilikleri uyumlu olarak bulunmuştur. Bireylerin gelir getiren bir işte çalışmaları, eğitim ve gelir düzeylerinin yüksek olması kaygı düzeylerini azaltmakta, sosyal destek algılarını ise arttırmaktadır. Bireylerin kaygı düzeyleri arttıkça, sosyal destek algısı ve evlilik uyumları azalmaktadır.

Anahtar kelimeler: İnfertilite, kaygı, sosyal destek, evlilik uyumu.

Received / Gelis tarihi: 21.01.2021, Accepted / Kabul tarihi: 31.07 .2021

${ }^{1}$ Uzman Ebe. Sağlık Bakanlığı Adana İl Sağlık Müdürlüğü Acil Sağlık Hizmetleri Başkanlığı, ADANA (ORCID: 0000-0003-0580-1758)

${ }^{2}$ Doç. Dr, Çukurova Üniversitesi Sağlık Bilimleri Fakültesi, Ebelik Bölümü, ADANA (ORCID: 0000-0002-5403-3778)

*Address for Correspondence / Yazışma Adresi: Adana İl Sağlık Müdürlüğü Acil Sağlık Hizmetleri Başkanlığı Seyhan/ADANA-TÜRKIYE, E-mail: aysenoglu@gmail.com

Şenoğlu A, Alan S. İnfertil Bireylerin Kaygı Düzeyleri, Sosyal Destek Algısı ve Evlilik Uyumu Açısından İncelenmesi TJFMPC, 2021;15(4): 661-675.

DOI: $10.21763 /$ tjfmpc.865981 


\section{Gİiş̧}

İnfertilite, 35 yaşından küçük kadınlarda 12 ay, 35 yaşından büyük kadınlarda altı ay boyunca, çiftlerin herhangi bir korunma yöntemi kullanmamaları ve düzenli cinsel ilişkide bulunmalarına rağmen gebeliğin oluşmaması olarak tanımlanmaktadır. ${ }^{1-4}$ Hem kadın, hem de erkekten kaynaklanan bir problem olan infertilite, çiftlerin yaklaşık \%15'ini etkilemekte olup, her geçen gün insidansı artmaktadır. $^{4}$ Kadınlarda, yaşa bağlı olarak fertilitede azalma görülmektedir. ${ }^{5}$ Stresli yaşam tarzı değişiklikleri, sağlıksız beslenme, sigara kullanımının artması gibi nedenler çiftlerde infertilitenin görülme sıklığını arttırmaktadır. ${ }^{6}$

Yetişkin bireyler için aile kurmak ve çocuk sahibi olmak beklenen bir amaç olmaktadır. Birçoğu doğal yollarla ve sağlıklı bir şekilde gebeliğin tamamlanması sonucunda çocuk sahibi olabilirken, bazıları bunun için birçok kez mücadele etmek durumunda kalabilmektedir. ${ }^{7,8} \mathrm{Bu}$ durum bireylerde strese yol açabilir. Bu nedenle infertilite yoğun bir duygusal deneyimdir. Hem kadını, hem de erkeği etkileyen stres, öz saygıyı kaybetme, üzüntü, suçluluk duygusu, utanç, kaygı, hayal kırıklığı, keder, yalnızlık gibi duyguları da içinde barındırır. İnfertil çiftlerin yaşadığı bu psikolojik problemlerin incelenmesi amacıyla bir çok çalışma yapılmıştır. $^{2} \mathrm{Bu}$ gruptaki depresyonun yaygınlığına bakıldığında, kadınların erkeklerden daha fazla etkilendiği belirtilmiştir. ${ }^{2}$ İnfertilite nedeni kadın kaynaklı olmasa da tedavi sürecinde yapılacak olan uygulamalar, kadının bedenine uygulanacağı için onlar daha fazla stres ve kaygı yaşamaktadır. ${ }^{5}$ Bununla birlikte erkekler de sürekli destekleyici rolünü üstlenmelerinden dolayı kendilerini bask1 altında hissedebilmekte ve bu nedenle kendi streslerini daha az ortaya koyabilmektedir. ${ }^{2}$

İnfertilite tıbbi, psikolojik ve sosyal sorunları beraberinde getiren, kültürel, dinsel ve sınıfsal yönleri olan bir süreçtir. Ayrıca, bireye özel, beklenmeyen stresörlerle karşılaştıran, toplumsal etiketlenmeyle sonuçlanan, cinsellikle ilgili başarısızlık, yetersizlik duyguları yaşanmasına neden olan ve yaşamı her yönü ile değiştiren bir deneyimdir. Tüm bu nedenlerden dolayı infertilite tanısı çiftlerde nasıl başa çıkacaklarını bilmedikleri bir kriz meydana getirmektedir. ${ }^{9}$ Infertilitenin etkilerini azaltmak için, baş etme yöntemlerinden olan aile ve eş desteği de bu süreçte kullanılan önemli bir sosyal destek kaynaklarıdır. Ayrıca, sosyal destek, infertil çiftlerde yaşam kalitesini ve evlilik uyumunu etkileyen faktörlerden biridir. ${ }^{10,11}$

İnfertilite, çiftlerin uyumunu etkileyen zorlu bir süreçtir. ${ }^{12,13}$ Bireylerin karşı karşıya kaldıkları fertilite sorunlarının çift ilişkileri üzerindeki etkisi farklılıklar göstermektedir. ${ }^{14}$ İnfertilitenin çiftlerin psikolojik iyilik halini ve cinsel ilişkilerini olumsuz yönde etkilediğine dair kanıtlar bulunmakla birlikte, evlilik uyumunu azalttığına yönelik kesin bir şey söylemek mümkün olmamaktadır. ${ }^{15,16}$ Bazı çalışmalar çiftlerde, infertilitenin yarattığ 1 hayal kırıklıkları, stres, kayg1, yas ve sosyal çevreden izole olmalarının, evlilik ilişkilerini daha da güçlendirdiği, evliliğe uyumunu arttırdığı yönündedir. ${ }^{17}$

İnfertilitenin yarattığı sorunlarla baş etmede çiftlere destek olmak gerekir. Literatür, infertil bireylerin psikososyal desteğe ihtiyaçlarının olduğunu ortaya koymaktadır. ${ }^{18}$ Danışmanlık hizmeti, infertil bireyler veya çiftler için en yaygın olarak kabul edilen psikososyal müdahalelerdir. ${ }^{19}$ Ülkemizde infertilite tedavisi alan bireylere, medikal tedavinin yanında psikolojik destek verilmesi henüz yaygın değildir. Üreme sağlı̆̆ hizmeti veren tüm sağlık profesyonelleri, infertil bireylere bu kapsamda danışmanlık hizmeti vererek hem bireylerin sorunlarının saptanmasına, hem de sorunları ile baş edebilmesine önemli katkı sağlayabilir. $\mathrm{Bu}$ doğrultuda infertil çiftlerin yaşadıkları psikososyal problemlerin bilinmesi, onların infertiliteye ve tedaviye uyumunu kolaylaştırabilir ve olumsuz tepkilerini azaltabilir. Ayrıca, sunulan danışmanlık hizmeti ile çiftlerin kendileri ile ilgili özel ihtiyaçlarını belirleyebilmeleri ve buna yönelik uygun kararlar alabilmeleri sağlanabilir. Bu bilgiler kapsamında araştırma, infertil bireylerin kaygı düzeylerinin, sosyal destek algılarının ve evlilik uyumlarının incelenmesi amacıyla yapılmıştır.

\section{YÖNTEM}

\section{Araştırmanın Türü}

$\mathrm{Bu}$ araştırma tanımlayıcı olarak yapılmıştır.

\section{Araştırmanın Evreni ve Örneklemi}

Araştırmanın evrenini, Ekim-Nisan 2017 tarihleri arasında, Türkiye'de, Adana ilinde özel bir hastanenin tüp bebek merkezi ile bir üniversite hastanesinin infertilite polikliniğine başvuran bireyler oluşturmuştur. Araştırmanın örneklem grubunu ise tüp bebek merkezine ve infertilite polikliniğine başvuran bireyler oluşturmuştur. Araştırmanın örneklemine alınması gereken en az birey sayısı power analiz ile belirlenmiştir. Power analiz yapıldığında örneklem büyüklüğü, 0,05 yanılg1 düzeyi, \%80 temsil gücü ve $\% 90$ güven aralığ 1 ile 187 kişi olarak hesaplanmıştır $(\mathrm{N}=600)$. Olası veri kayıpları göz önünde bulundurularak 184 kadın ve 77 erkek olmak üzere toplam 261 kişi ile araştırma tamamlanmıştır. Araştırmaya çift olarak katılanlarda, sosyo-demografik ve tıbbi-obstetrik bilgiler sadece kadınlardan alınmıştır.

\section{Araştırmaya Dahil Edilme ve Dışlanma Kriterleri}


Araştırmaya 18 yaşından büyük, infertilite polikliniğine ve tüp merkezine başvuran, iletişim güçlüğü olmayan kadın ve erkekler dahil edilmiş, araştırmanın dışlanma kriterini ise Türkçe bilmeme ve herhangi bir ruhsal bozukluk tanısı konulma, işitme- konuşma güçlüğü bulunması oluşturmuştur.

\section{Veri Toplama Araçları}

Veriler, araştırmacılar tarafından literatür doğrultusunda geliştirilen, 34 sorudan oluşan Soru Formu, Durumluk-Sürekli Kaygı Ölçeği (STAI III), Çok Boyutlu Algılanan Sosyal Destek Ölçeği (ÇBASDÖ) ve Evlilikte Uyum Ölçeği (EUÖ) formları kullanılarak toplanmıştır.

\section{Durumluk-Sürekli Kaygı Ölçeği (STAI I-II)}

STAI I-II 1970 yılında Spielberger ve arkadaşları tarafından geliştirilmiş, Öner ve Le Comte tarafından 1983 yılında Türkçe 'ye uyarlanmıştır. Ölçek 14 yaş üstü bireylere uygulanabilmektedir. Durumluk Kaygı Ölçeği, 20 maddeden oluşan, ani değişiklik gösteren reaksiyonları değerlendirmede oldukça duyarlı bir araçtır. İkinci bölümünde yer alan, yine 20 maddeden oluşan Sürekli Kaygı Ölçeği, kişinin genelde yaşama eğilimi gösterdiği kaygının sürekliliğini ölçmeyi amaçlamaktadır. Durumluk-Sürekli Kaygı Ölçeğinde toplam 40 soru bulunmaktadır. Her iki ölçekten elde edilen puanlar kuramsal olarak 20 ile 80 arasında değişmektedir. Yüksek puan yüksek kaygı seviyesini, düşük puan düşük kaygı seviyesini ifade etmektedir. Dört puanlık Likert tipi ölçüm sağlamaktadır. Bir puan, soruda belirtilen durumun kendilerini hiç yansıtmadığını; 4 puan, soruda belirtilen durumun kendilerini tamamen yansıttığını göstermektedir. Ölçeğin cronbach alfa güvenirlik katsayısı, Sürekli Kayg1 Ölçeği için 0,83 ile 0,87 arasında; Durumluk Kayg1 Ölçeği için 0,94 ile 0,96 arasında olduğu belirtilmiştir. Bu araştırmada, Sürekli Kaygı Ölçeği cronbach alpha güvenirlik katsayısı 0,751; Durumluk Kayg1 Ölçeği için 0,680 olarak bulunmuştur. ${ }^{20}$

\section{Çok Boyutlu Algılanan Sosyal Destek Ölçeği}

Ölçek, Zimmet ve ark. tarafından bireylerin algıladıkları sosyal destek unsurlarını belirlemeye yönelik olarak geliştirilmiş, Eker ve Arkar tarafından Türkçe, geçerlik ve güvenirlik çalışması yapılmıştır. ÇBASDÖ üç farklı kaynaktan (aile, arkadaş ve özel bir insan) alınan sosyal desteğin yeterliliğini öznel olarak değerlendiren, kullanımı kolay, 12 maddeden oluşan bir ölçektir. Alt ölçeklerden alınabilecek en düşük puan 4, en yüksek puan 28'dir. Ölçeğin tamamından elde edilecek en düşük puan 12, en yüksek puan 84'tür. Elde edilen puanın yüksek olması, algılanan sosyal desteğin yüksek olduğunu göstermektedir. Ölçeğin, cronbach alfa güvenirlik katsayısı 0,89 olduğu belirtilmiştir. ${ }^{21} \mathrm{Bu}$ araştırmada ölçeğin cronbach alpha güvenirlik katsayısı 0,935 olarak bulunmuştur.

\section{Evlilikte Uyum Ölçeği}

EUÖ, Locke ve Wallace tarafından, evliliğin niteliğini ölçmek amaciyla geliştirilmiş, Tutarel Kışlak tarafından Türkçe güvenirlik ve geçerlik çalışması yapılmıştır. Ölçeğin 15 maddesi bulunmaktadır. Ölçek hem genel evlilik doyumunu ya da niteliğini ölçmekte, hem de çeşitli konularda (aile bütçesi, duyguların ifadesi, arkadaşlar, cinsellik, toplumsal kurallar, yaşam felsefesi) anlaşma ya da anlaşmama ile ilişki tarzını (boş zaman, ev dışı etkinlikler, çatışma çözme, güven) ölçmektedir.

Ölçekten alınabilecek en düşük puan 1, en yüksek puan 60 olarak belirlenmiştir. Ölçeğin kesim noktası 43 olarak belirlenmiş olup, evli kişiler 43 ve üzeri puan almışlarsa evliliklerinde uyumlu, 43 altı puan almışlarsa evliliklerinde uyumsuz olarak değerlendirilmektedir. Ölçeğin cronbach alfa güvenirlik katsayısı 0,90 olarak belirtilmiştir. $^{22} \mathrm{Bu}$ araştırmada ölçeğin cronbach alpha güvenirlik katsayısı 0,852 olarak bulunmuştur.

\section{Verilerin Toplanması}

Araştırma verileri, birinci araştırmacı tarafından toplanmıştır. Okuma yazma bilen bireyler verileri kendileri doldurmuş, okuma yazma bilmeyenler ise araştırmacı tarafından mahremiyetin sağlandığı bir odada yüz yüze görüşülerek doldurulmuştur. Beden Kitle İndeksi, soru formunda bireylere sorulan boy ve kilo bilgilerine göre kilonun, boy değerinin karesine bölünmesiyle hesaplanmıştır.

\section{Verilerin Değerlendirilmesi ve Analizi}

Elde edilen verilerin analizlerinde SPSS (IBM SPSS Statistics 20) programı kullanılmıştır. Bulguların yorumlanmasinda, frekans tabloları ve tanımlayıcı (sayı, yüzde dağılımları, ortalama, standart sapma, ortanca) istatistikler kullanılmıştır. Normal dağılıma uygun ölçüm değerleri için parametrik yöntemler kullanılmıştır. Parametrik yöntemlere uygun şekilde, iki bağımsız grubun ölçüm değerleri ile karşılaştırılmasında bağımsız gruplarda t test, bağımsız üç veya daha fazla grubun ölçüm değerleri ile karşılaştırılmasında ANOVA, üç veya daha fazla grup için anlamlı fark çıkan değişkenlerin ikili karşılaştırmaları için varyansların homojenliği göz önüne alınarak varyanslar homojense Tukey, değilse Tamhane test istatistikleri kullanılmıştır. Normal dağılıma uygun olmayan ölçüm değerleri için parametrik olmayan 
yöntemler kullanılmıştır. Parametrik olmayan yöntemlere uygun şekilde, iki bağımsız grubun ölçüm değerleri ile karşılaştırılmasında MannWhitney U test, bağımsız üç veya daha fazla grubun ölçüm değerleri ile karşılaştırılmasında Kruskal-Wallis H test, üç veya daha fazla grup için anlamlı fark çıkan değişkenlerin ikili karşılaştırmaları için Bonferroni düzeltmesi uygulanmıştır. Normal dağılıma sahip olmayan ölçüm değerlerinin birbirleriyle ilişkisinin incelenmesinde Spearman Korelasyon katsayısı kullanılmıştır.

\section{Araștırmanın Etik Boyutu}

Araştırma için, Çukurova Üniversitesi Tıp Fakültesi Girişimsel Olmayan Klinik Araştırmalar Etik Kurulu'ndan onay (07/10/2016 - 57/21), araştırmanın yapılacağ ve ölçeği geliştiren kişilerden ölçek için kullanım izni, araştırmaya dahil edilen bireylerden araştırmaya yönelik aydınlatılmış onam alınmıştır.

\section{BULGULAR}

$\mathrm{Bu}$ araştırmada, infertil bireylerin sosyodemografik özelliklerine yönelik bulgular Tablo 1' de, infertil kadınların tıbbi ve obstetrik özelliklerine yönelik bulgular ise Tablo 2' de verilmiştir.

Tablo 1. İnfertil Bireylerin Sosyo-Demografik Özelliklerinin Dağılımı

\begin{tabular}{|c|c|c|}
\hline Değişken Değişkenler & N (261) & $\%$ \\
\hline \multicolumn{3}{|l|}{ Cevaplanma Durumu } \\
\hline Çift Olarak Cevaplayan & 150 & 57,5 \\
\hline Yalnız Başına Cevaplayan & 111 & 42,5 \\
\hline \multicolumn{3}{|l|}{ Cinsiyet } \\
\hline Kadın & 184 & 70,5 \\
\hline Erkek & 77 & 29,5 \\
\hline \multicolumn{3}{|c|}{$\operatorname{Kadın}$ Yaş $[\overline{\mathrm{X}} \pm S . S . \rightarrow 32,16 \pm 6,98(y \iota l)]$} \\
\hline \multicolumn{3}{|c|}{ Eş Yaş $\left[\overline{\mathrm{X}} \pm S . S . \rightarrow 33,56 \pm 6,79\left(y_{l} l\right)\right]$} \\
\hline \multicolumn{3}{|l|}{ Beden Kitle İndeksi } \\
\hline Zayıf $<18,50$ & 8 & 4,3 \\
\hline $18,50 \leq$ Normal $\leq 24,99$ & 91 & 48,9 \\
\hline $250 \geq$ Toplu, hafif şişman, fazla kilolu & 87 & 46,8 \\
\hline \multicolumn{3}{|l|}{ Evlilik Süresi $[\overline{\mathrm{X}} \pm$ S.S. $\rightarrow \mathbf{5 , 9 3} \pm 4,94(\mathrm{yll})]$} \\
\hline $1 \mathrm{Y}$ il & 28 & 10,7 \\
\hline 2-4 Y1l & 110 & 42,1 \\
\hline 5-7 Y11 & 55 & 21,1 \\
\hline 8 Y1l ve Üzeri & 68 & 26,1 \\
\hline \multicolumn{3}{|l|}{ Eğitim Durumu } \\
\hline Okuryazar Değil & 12 & 4,5 \\
\hline Okuryazar & 4 & 1,5 \\
\hline İlkokul & 44 & 16,9 \\
\hline Ortaokul & 49 & 18,8 \\
\hline Lise & 73 & 28 \\
\hline Üniversite ve Üzeri & 79 & 30,3 \\
\hline \multicolumn{3}{|l|}{ Eş Eğitim Durumu } \\
\hline Okuryazar Değil & 10 & 3,8 \\
\hline Okuryazar & 7 & 2,7 \\
\hline İlkokul & 45 & 17,2 \\
\hline Ortaokul & 51 & 19,5 \\
\hline Lise & 67 & 25,7 \\
\hline Üniversite ve Üzeri & 81 & 31,1 \\
\hline \multicolumn{3}{|l|}{ Çalıșma Durumu (Kadın) } \\
\hline Evet & 46 & 25 \\
\hline Hayır & 138 & 75 \\
\hline \multicolumn{3}{|l|}{ Çalıșma Durumu (Erkek) } \\
\hline Evet & 71 & 92,2 \\
\hline Hayır & 6 & 7,8 \\
\hline \multicolumn{3}{|l|}{ Gelir Düzeyi } \\
\hline Düşük & 30 & 11,5 \\
\hline Orta & 183 & 70,1 \\
\hline Yüksek & 48 & 18,4 \\
\hline Toplam & 261 & 100 \\
\hline
\end{tabular}

$\overline{\mathrm{X}}=$ Ortalama; S.S. $=$ Standart sapma 
Tablo 2. İnfertil Kadınların Tıbbi ve Obstetrik Özelliklerine Yönelik Bulguların Dağılımı

\begin{tabular}{|c|c|c|}
\hline Değişkenler & N (186)* & $\%$ \\
\hline \multicolumn{3}{|l|}{ Kronik Hastalık } \\
\hline Evet & 18 & 9,7 \\
\hline Hayır & 168 & 90,3 \\
\hline \multicolumn{3}{|l|}{ Kadın Sağlığg Sorunu } \\
\hline Evet & 43 & 23,4 \\
\hline Hayır & 141 & 76,6 \\
\hline \multicolumn{3}{|c|}{ Doğum Kontrol Yöntemi Kullanma } \\
\hline Evet & 43 & 23,4 \\
\hline Hayır & 141 & 76,6 \\
\hline \multicolumn{3}{|l|}{ Doğum Kontrol Yöntemi } \\
\hline Doğum Kontrol Hapı & 14 & 32,6 \\
\hline Rahim İçi Araç & 7 & 16,2 \\
\hline Kondom & 10 & 23,3 \\
\hline Geri Çekme & 12 & 27,9 \\
\hline \multicolumn{3}{|l|}{ Gebe Kalma Durumu } \\
\hline Evet & 62 & 34,8 \\
\hline Hayır & 116 & 65,2 \\
\hline \multicolumn{3}{|l|}{ İnfertilite Nedeni } \\
\hline Erkek Faktör & 34 & 18,3 \\
\hline Kadın Faktör & 58 & 31,2 \\
\hline Hem Erkek Hem Kadın Faktör & 24 & 12,9 \\
\hline Açıklanamayan İnfertilite & 70 & 37,6 \\
\hline \multicolumn{3}{|l|}{ İnfertilite Yılı } \\
\hline $1 \mathrm{Y}_{11}$ & 39 & 21 \\
\hline $2 Y_{11}$ & 30 & 16,1 \\
\hline 3 Y1l ve üzeri & 117 & 62,9 \\
\hline \multicolumn{3}{|l|}{ Cinsel İlişki Sayısı (Hafta) } \\
\hline \multicolumn{3}{|l|}{$[\overline{\mathrm{X}} \pm$ S.S. $\rightarrow 2,73 \pm 1,59]$} \\
\hline $1 \mathrm{Kez}$ & 33 & 15,4 \\
\hline $2 \mathrm{Kez}$ & 69 & 32,2 \\
\hline $3 \mathrm{Kez}$ & 71 & 33,2 \\
\hline 4 ve Üzeri & 41 & 19,2 \\
\hline \multicolumn{3}{|c|}{ İnfertilite Tedavisi Alma Durumu } \\
\hline Evet & 158 & 84,9 \\
\hline Hayır & 28 & 15,1 \\
\hline \multicolumn{3}{|c|}{ İnfertilite Tedavi Yılı $[\bar{X} \pm$ S.S. $\rightarrow 2,24 \pm 1,126]$} \\
\hline 1 Yildan Az & 54 & 33,5 \\
\hline $1-2 Y_{11}$ & 45 & 28 \\
\hline 3-5 Y1l & 34 & 21,1 \\
\hline 6 Y1l ve Üzeri & 28 & 17,4 \\
\hline Toplam & 186 & 100 \\
\hline
\end{tabular}

*Kadınların tıbbi ve obstetrik özelliklerine yönelik soruları 2 erkek katılımcı eşlerine yönelik olarak kendileri cevaplamıştır. $\overline{\mathrm{X}}=$ Ortalama; S.S. $=$ Standart sapma 
Tablo 3. İnfertil Bireylerin Sosyo-Demografik Özelliklerine Yönelik Değişkenleri ile Durumluk-Sürekli Kayg1 Ölçeği, ÇBASDÖ ve EUÖ Puanlarının Karşılaştırılması

\begin{tabular}{|c|c|c|c|c|c|c|c|c|}
\hline \multirow[t]{2}{*}{ Değişken (N=261) } & \multirow[b]{2}{*}{$\mathbf{n}$} & \multicolumn{2}{|c|}{ Kaygı Ölçeği } & \multicolumn{4}{|c|}{$* * *$ ÇBASDÖ } & \multirow[t]{2}{*}{$* * * * \mathbf{E U O ̈}$} \\
\hline & & Durumluk & Sürekli & Aile & Arkadaş & Özel Kişi & Toplam & \\
\hline *Cevaplanma & & Ortanca (min-max) & Ortalama \pm SS & Ortanca (min-max) & Ortanca (min-max) & Ortanca (min-max) & Ortanca (min-max) & Ortanca (min-max) \\
\hline Çift Olarak & 150 & $35[20-76]$ & $42,18 \pm 8,92$ & $24[4-28]$ & $17,5[4-28]$ & $17[4-28]$ & $57,5[16-84]$ & $48[21-60]$ \\
\hline \multirow[t]{3}{*}{ Yalnız Başına } & 111 & 38 [20-65] & $45,32 \pm 8,73$ & $25[4-28]$ & $14[4-2]$ & $16[4-28]$ & $55[12-84]$ & $48[6-60]$ \\
\hline & & $Z=-1,244$ & $\mathrm{t}=-2,833$ & $Z=-0,311$ & $Z=-1,675$ & $Z=-0,413$ & $Z=-0,739$ & $Z=-1,293$ \\
\hline & & $\mathrm{p}=0,214$ & $p=0,005$ & $\mathrm{p}=0,576$ & $\mathrm{p}=0,094$ & $\mathrm{p}=0,679$ & $\mathrm{p}=0,460$ & $\mathrm{p}=0,196$ \\
\hline$* *$ Cinsiyet & & Ortanca (min-max) & Ortalama \pm SS & Ortanca (min-max) & Ortanca (min-max) & Ortanca (min-max) & Ortanca (min-max) & Ortanca (min-max) \\
\hline Kadın & 184 & $37[20-71]$ & $44,96 \pm 8,44$ & $25[4-28]$ & $16[4-2]$ & $16,5[4-28]$ & $56[12-84]$ & $48[6-60]$ \\
\hline \multirow[t]{3}{*}{ Erkek } & 77 & 35 [20-76] & $405 \pm 9,26$ & $23[4-28]$ & $19[4-28]$ & $17[4-28]$ & 59 [18-84] & $48[23-60]$ \\
\hline & & $Z=-1,591$ & $\mathrm{t}=4,164$ & $Z=-1,668$ & $Z=-1,340$ & $Z=-0,442$ & $Z=-0,181$ & $Z=-015$ \\
\hline & & $\mathrm{p}=0,112$ & $\mathrm{p}=\mathbf{0 , 0 0 0}$ & $\mathrm{p}=0,095$ & $\mathrm{p}=0,180$ & $\mathrm{p}=0,659$ & $\mathrm{p}=0,857$ & $\mathrm{p}=0,988$ \\
\hline **Beden Kitle İndeksi & & Ortanca (min-max) & Ortalama \pm SS & Ortanca (min-max) & Ortanca (min-max) & Ortanca (min-max) & Ortanca (min-max) & Ortanca (min-max) \\
\hline Zayif < 18,50 (1) & 8 & $39[20-54]$ & $46,13 \pm 86$ & $26,5[18-28]$ & $14[4-25]$ & $18,5[4-26]$ & $59,5[36-62]$ & $49[35-56]$ \\
\hline Normal $^{(2)}$ & 91 & $36[20-71]$ & $453 \pm 9,34$ & $28[4-28]$ & $15[4-28]$ & $18[4-28]$ & $58[13-84]$ & 48 [10-60] \\
\hline \multirow[t]{4}{*}{$250 \geq$ Şişman $^{(3)}$} & 87 & 38 [23-65] & $44,66 \pm 7,68$ & $22[4-28]$ & $16[4-28]$ & $16[4-28]$ & $50[12-84]$ & 48 [6-59] \\
\hline & & $\chi^{2}=0,365$ & $\mathrm{~F}=0,129$ & $\chi^{2}=6,327$ & $\chi^{2}=0,867$ & $\chi^{2}=062$ & $\chi^{2}=0,621$ & $\chi^{2}=0,139$ \\
\hline & & $\mathrm{p}=0,833$ & $\mathrm{p}=0,879$ & $p=0,042$ & $\mathrm{p}=0,648$ & $p=0,970$ & $\mathrm{p}=0,733$ & $\mathrm{p}=0,933$ \\
\hline & & - & - & {$[2-3]$} & - & - & - & - \\
\hline *Evlilik Süresi & & Ortanca (min-max) & Ortalama $\pm \mathrm{SS}$ & Ortanca (min-max) & Ortanca (min-max) & Ortanca (min-max) & Ortanca (min-max) & Ortanca (min-max) \\
\hline $1 \mathrm{Y}_{1} \mathrm{l}^{(1)}$ & 28 & 35,5 [20-67] & $42,86 \pm 8,83$ & $25,5[4-28]$ & $18,5[4-28]$ & $16,5[4-28]$ & $57,5[18-84]$ & 49,5 [36-57] \\
\hline $2-4 Y_{1} 1^{(2)}$ & 110 & $35[20-76]$ & $44,15 \pm 9,33$ & $24[4-28]$ & $17[4-28]$ & $18[4-28]$ & $59,5[12-84]$ & $47,5[10-60]$ \\
\hline $5-7 Y_{1} 1^{(3)}$ & 55 & $36[20-56]$ & $43,40 \pm 9,35$ & $25[4-28]$ & $17[4-28]$ & $17[4-28]$ & 55 [18-84] & 50 [32-60] \\
\hline \multirow[t]{4}{*}{8 Y1l ve Üzeri ${ }^{(4)}$} & 68 & $38,5[20-65]$ & $42,84 \pm 8,15$ & $24[4-28]$ & $14[4-28]$ & $15,5[4-28]$ & 54 [12-84] & $47,5[6-58]$ \\
\hline & & $\chi^{2}=2,140$ & $\mathrm{~F}=0,367$ & $\chi^{2}=0,712$ & $\chi^{2}=2,479$ & $\chi^{2}=2,224$ & $\chi^{2}=1,379$ & $\chi^{2}=11,513$ \\
\hline & & $\mathrm{p}=0,544$ & $\mathrm{p}=0,777$ & $\mathrm{p}=0,870$ & $\mathrm{p}=0,479$ & $\mathrm{p}=0,527$ & $\mathrm{p}=0,710$ & $\mathrm{p}=\mathbf{0 , 0 0 9}$ \\
\hline & & - & - & - & - & - & - & {$[2,4-3]$} \\
\hline **Eğitim Durumu & & Ortanca (min-max) & Ortanca (min-max) & Ortanca (min-max) & Ortanca (min-max) & Ortanca (min-max) & Ortanca (min-max) & Ortanca (min-max) \\
\hline Okur Y, Değil ${ }^{(1)}$ & 12 & $36,5[26-60]$ & 48 [36-53] & $20[4-28]$ & $14,5[4-28]$ & $15,5[4-2]$, & $47[25-83]$ & $49,5[19-56]$ \\
\hline İlkokul ${ }^{(2)}$ & 44 & $39[21-65]$ & $44,5[20-68]$ & $23,5[4-28]$ & $13[4-28]$ & $14[4-28]$ & $51,5[12-84]$ & $48,5[10-59]$ \\
\hline Ortaokul ${ }^{(3)}$ & 49 & 37 [20-67] & $44,5[23-57]$ & $16[4-28]$ & 13 [4-28] & $13[4-28]$ & $40[12-84]$ & $49[6-59]$ \\
\hline Lise $^{(4)}$ & 73 & $35[20-76]$ & $45[24-73]$ & 25 [4-28] & $16[4-28]$ & 19 [4-28] & $59[13-84]$ & $48[18-58]$ \\
\hline \multirow[t]{3}{*}{ Üniversite ve $\uparrow^{(5)}$} & 79 & $36[20-73]$ & $40[20-70]$ & $27[4-28]$ & 23 [4-28] & 22 [4-28] & 72 [12-84] & 48 [31-60] \\
\hline & & $\begin{aligned} \chi^{2} & =1,731 \\
p & =0,785\end{aligned}$ & $\begin{array}{c}\chi^{2}=11,828 \\
\mathbf{p}=\mathbf{0 , 0 1 9}\end{array}$ & $\begin{array}{c}\chi^{2}=11,812 \\
\mathbf{p}=\mathbf{0 , 0 1 9}\end{array}$ & $\begin{array}{l}\chi^{2}=2537 \\
\mathbf{p}=\mathbf{0 , 0 0 0}\end{array}$ & $\begin{aligned} \chi^{2} & =15,731 \\
\mathbf{p} & =\mathbf{0 , 0 0 3}\end{aligned}$ & $\begin{aligned} \chi^{2} & =22,225 \\
& =0.000\end{aligned}$ & $\begin{array}{l}\chi^{2}=1,122 \\
=00891\end{array}$ \\
\hline & & - & {$[1,4-5]$} & {$[3-4,5]$} & {$[1,2,3,4-5]$} & {$[2,3-5][3-4]$} & {$[1,2,3-5][3-4]$} & $p=-0,091$ \\
\hline **Çalışma Durumu & & Ortanca (min-max) & Ortalama $\pm S S$ & Ortanca (min-max) & Ortanca (min-max) & Ortanca (min-max) & Ortanca (min-max) & Ortanca (min-max) \\
\hline Evet & 137 & $35[20-76]$ & $41,29 \pm 9,33$ & $25[4-28]$ & $20[4-28]$ & $19[4-28]$ & $62[13-84]$ & $48[25-60]$ \\
\hline \multirow[t]{3}{*}{ Hayır } & 124 & 38 [20-65] & $45,31 \pm 8,24$ & $24[4-28]$ & 14 [4-28] & 16 [4-28] & $48,5[12-84]$ & $48[6-60]$ \\
\hline & & $Z=-1,774$ & $\mathrm{t}=-3,701$ & $Z=-045$ & $Z=-3,389$ & $Z=-1,591$ & $Z=-239$ & $Z=-0,444$ \\
\hline & & $\mathrm{p}=0,076$ & $\mathrm{p}=\mathbf{0 , 0 0 0}$ & $\mathrm{p}=0,964$ & $\mathrm{p}=\mathbf{0 , 0 0 1}$ & $\mathrm{p}=0,112$ & $p=0,041$ & $\mathrm{p}=0,657$ \\
\hline
\end{tabular}




\begin{tabular}{|c|c|c|c|c|c|c|c|c|}
\hline **Gelir Düzeyi & & Ortanca (min-max) & Ortanca (min-max) & Ortanca (min-max) & Ortanca (min-max) & Ortanca (min-max) & Ortanca (min-max) & Ortanca (min-max) \\
\hline Düşük ${ }^{(1)}$ & 30 & $43[21-65]$ & $48,5[36-68]$ & $19[4-28]$ & $9,5[4-24]$ & $13[4-28]$ & $42,5[16-74]$ & $48[19-59]$ \\
\hline Orta ${ }^{(2)}$ & 183 & $36[20-76]$ & $44[20-70]$ & $25[4-28]$ & $17[4-28]$ & $16[4-28]$ & 58 [12-84] & 49 [6-60] \\
\hline Yüksek (3) & 48 & 34 [20-73] & $41[27-73]$ & $25[4-28]$ & $19,5[4-28]$ & $21[4-28]$ & $60[12-84]$ & $46[10-58]$ \\
\hline & & $\begin{array}{c}\chi^{2}=743 \\
\mathbf{p}=\mathbf{0 , 0 3 0} \\
{[\mathbf{1 - 2 , 3}]}\end{array}$ & $\begin{array}{c}\chi^{2}=15,444 \\
\mathbf{p}=\mathbf{0 , 0 0 0} \\
{[\mathbf{1 - 2 , 3}]}\end{array}$ & $\begin{array}{c}\chi^{2}=5,514 \\
\mathrm{p}=0,063 \\
-\end{array}$ & $\begin{array}{c}\chi^{2}=12,858 \\
\mathbf{p}=\mathbf{0 , 0 0 2} \\
{[\mathbf{1 - 2 , 3}]}\end{array}$ & $\begin{array}{c}\chi^{2}=4,288 \\
\mathrm{p}=0,117 \\
-\end{array}$ & $\begin{array}{c}\chi^{2}=1185 \\
\mathbf{p}=\mathbf{0 , 0 0 4} \\
{[\mathbf{1 - 2 , 3}]}\end{array}$ & $\begin{array}{c}\chi^{2}=5,976 \\
\mathrm{p}=0,051 \\
-\end{array}$ \\
\hline
\end{tabular}

**Mann-Whitney U testi; üç veya daha fazla grubun karşllaştırılmasında Kruskal-Wallis H testi.***ÇBASDÖ: Çok Boyutlu Algıllanan Sosyal Destek Ölçeği. .**** EUÖ: Evlilikte Uyum Ölçeği

Tablo 4. İnfertil Bireylerin Tıbbi ve Obstetrik Özelliklerine Yönelik Değişkenleri İle Durumluk-Sürekli Kaygı Ölç̧ği, ÇBASDÖ ve EUÖ Karşılaştırılması

\begin{tabular}{|c|c|c|c|c|c|c|c|c|}
\hline \multirow[t]{2}{*}{ Değişken ( $N=261)$} & \multirow[b]{2}{*}{$\mathbf{n}$} & \multicolumn{2}{|c|}{ Kaygı Ölçeği } & \multicolumn{4}{|c|}{$* *$ CBASDÖ } & \multirow{2}{*}{$* * * * \mathbf{E U O ̈}$} \\
\hline & & Durumluk & Sürekli & Aile & Arkadaş & Özel Kişi & Toplam & \\
\hline *Kronik Hastalık & & Ortanca (min-max) & Ortalama \pm SS & Ortanca (min-max) & Ortanca (min-max) & Ortanca (min-max) & Ortanca (min-max) & Ortanca (min-max) \\
\hline Evet & 18 & $49[26-61]$ & $47,39 \pm 7,21$ & $24[4-28]$ & $12,5[4-28]$ & $17[4-28]$ & $43,5[13-84]$ & $46,5[31-59]$ \\
\hline Hayır & 168 & $36[20-71]$ & $44,64 \pm 8,62$ & 25 [4-28] & $16[4-28]$ & $16,5[4-28]$ & $57[12-84]$ & $48[6-60]$ \\
\hline & & $Z=-303$ & $\mathrm{t}=1,306$ & $\mathrm{Z}=-0,202$ & $Z=-197$ & $\mathrm{Z}=-028$ & $\mathrm{Z}=-0,500$ & $Z=-0,314$ \\
\hline & & $\mathrm{p}=\mathbf{0 , 0 0 3}$ & $\mathrm{p}=0,193$ & $\mathrm{p}=0,840$ & $\mathrm{p}=0,273$ & $\mathrm{p}=0,978$ & $\mathrm{p}=0,617$ & $\mathrm{p}=0,754$ \\
\hline **K,Sağlık Sorunu & & Ortanca (min-max) & Ortalama \pm SS & Ortanca (min-max) & Ortanca (min-max) & Ortanca (min-max) & Ortanca (min-max) & Ortanca (min-max) \\
\hline Evet & 43 & $45[20-65]$ & $472 \pm 9,94$ & $24[4-28]$ & $14[4-28]$ & $14[4-28]$ & $47[12-84]$ & $46[15-60]$ \\
\hline Hayır & 141 & $36[20-71]$ & $44,31 \pm 7,90$ & 25 [4-28] & $16[4-28]$ & 17 [4-28] & $57[12-84]$ & $49[6-59]$ \\
\hline & & $Z=-1,772$ & $\mathrm{t}=1,849$ & $\mathrm{Z}=-0,210$ & $\mathrm{Z}=-007$ & $Z=-0,766$ & $Z=-0,344$ & $\mathrm{Z}=-1,772$ \\
\hline & & $\mathrm{p}=0,076$ & $\mathrm{p}=0,066$ & $\mathrm{p}=0,834$ & $\mathrm{p}=0,995$ & $\mathrm{p}=0,444$ & $\mathrm{p}=0,731$ & $\mathrm{p}=0,076$ \\
\hline **Doğum Kontrol & & Ortanca (min-max) & Ortalama \pm SS & Ortanca (min-max) & Ortanca (min-max) & Ortanca (min-max) & Ortanca (min-max) & Ortanca (min-max) \\
\hline Evet & 43 & $37[24-63]$ & $45,12 \pm 8,99$ & $28[5-28]$ & $24[4-28]$ & $22[4-28]$ & $73[19-84]$ & $47[33-60]$ \\
\hline Hayır & 141 & $37[20-71]$ & $450 \pm 8,34$ & 23 [4-28] & 14 [4-28] & 16 [4-28] & $51[12-84]$ & 49 [6-59] \\
\hline & & $\mathrm{Z}=-0,109$ & $t=081$ & $Z=-2,907$ & $\mathrm{Z}=-375$ & $Z=-2,594$ & $\mathrm{Z}=-3,319$ & $Z=-1,199$ \\
\hline & & $\mathrm{p}=0,914$ & $\mathrm{p}=0,936$ & $\mathrm{p}=\mathbf{0 , 0 0 4}$ & $\mathrm{p}=\mathbf{0 , 0 0 2}$ & $p=0,009$ & $p=0,001$ & $\mathrm{p}=0,230$ \\
\hline$* *$ Gebe Kalma & & Ortanca (min-max) & Ortalama \pm SS & Ortanca (min-max) & Ortanca (min-max) & Ortanca (min-max) & Ortanca (min-max) & Ortanca (min-max) \\
\hline Evet & 62 & $36,5[20-65]$ & $44,98 \pm 8,51$ & $22,5[4-28]$ & $12[4-28]$ & $14[4-28]$ & $47,5[12-84]$ & $48[10-59]$ \\
\hline Hayır & 116 & $37,5[20-71]$ & $44,70 \pm 8,57$ & 25 [4-28] & $17,5[4-28]$ & 18 [4-28] & $60[12-84]$ & 48 [6-60] \\
\hline & & $\mathrm{Z}=-0,826$ & $\mathrm{t}=0,212$ & $Z=-1,152$ & $\mathrm{Z}=-2,499$ & $Z=1,945$ & $Z=-2,276$ & $\mathrm{Z}=-0,732$ \\
\hline & & $\mathrm{p}=0,409$ & $\mathrm{p}=0,832$ & $\mathrm{p}=0,249$ & $\mathrm{p}=\mathbf{0 , 0 1 2}$ & $\mathrm{p}=0,052$ & $\mathrm{p}=\mathbf{0 , 0 2 3}$ & $\mathrm{p}=0,464$ \\
\hline **Infertilite Nedeni & & Ortanca (min-max) & Ortalama \pm SS & Ortanca (min-max) & Ortanca (min-max) & Ortanca (min-max) & Ortanca (min-max) & Ortanca (min-max) \\
\hline Erkek Faktör & 34 & $41,5[20-71]$ & $44,29 \pm 8,24$ & $24,5[4-28]$ & $14[4-28]$ & $16,5[4-28]$ & $57,5[12-84]$ & $49[6-59]$ \\
\hline Kadın Faktör & 58 & $36[20-63]$ & $45,45 \pm 8,70$ & 28 [4-28] & $16,5[4-28]$ & $16[4-28]$ & $57,5[12-84]$ & $49[15-60]$ \\
\hline Erkek+Kadın Fa, & 24 & $34[20-61]$ & $44,75 \pm 10,97$ & 25 [4-28] & 12 [4-28] & 14 [4-28] & $46,5[12-84]$ & $49,5[10-58]$ \\
\hline Açıklanamayan & 70 & $37,5[20-65]$ & $44,80 \pm 7,66$ & 23 [4-28] & $17,5[4-28]$ & 18 [4-28] & 57,5 [13-84] & $46,5[10-59]$ \\
\hline & & $\chi^{2}=0,762$ & $\mathrm{~F}=0,141$ & $\chi^{2}=3,982$ & $\chi^{2}=109$ & $\chi^{2}=2,975$ & $\chi^{2}=1,403$ & $\chi^{2}=2,943$ \\
\hline & & $\mathrm{p}=0,858$ & $\mathrm{p}=0,935$ & $\mathrm{p}=0,263$ & $\tilde{p}=0,799$ & $\mathrm{p}=0,395$ & $\mathrm{p}=0,705$ & $\mathrm{p}=0,401$ \\
\hline **Infertilite Yılı & & Ortalama \pm SS & Ortalama \pm SS & Ortalama \pm SS & Ortalama \pm SS & Ortalama \pm SS & Ortalama \pm SS & Ortalama \pm SS \\
\hline 1 Yll & 39 & $39,5 \pm 10,94$ & $44,7 \pm 9,95$ & $225 \pm 7,53$ & $17,9 \pm 8,96$ & $16,9 \pm 8,54$ & $56,8 \pm 21,82$ & $47 \pm 75$ \\
\hline 2 Yil & 30 & $35 \pm 9,95$ & $44,3 \pm 8,83$ & $21,73 \pm 7,55$ & $17 \pm 8,42$ & $17,9 \pm 7,89$ & $56,6 \pm 21,49$ & $47,7 \pm 9,74$ \\
\hline 3 Yıl ve üzeri & 117 & $40,1 \pm 11,78$ & $45,1 \pm 7,96$ & $20,85 \pm 84$ & $15,3 \pm 8,55$ & $16,5 \pm 8,34$ & $52,6 \pm 215$ & $45,4 \pm 10,14$ \\
\hline
\end{tabular}




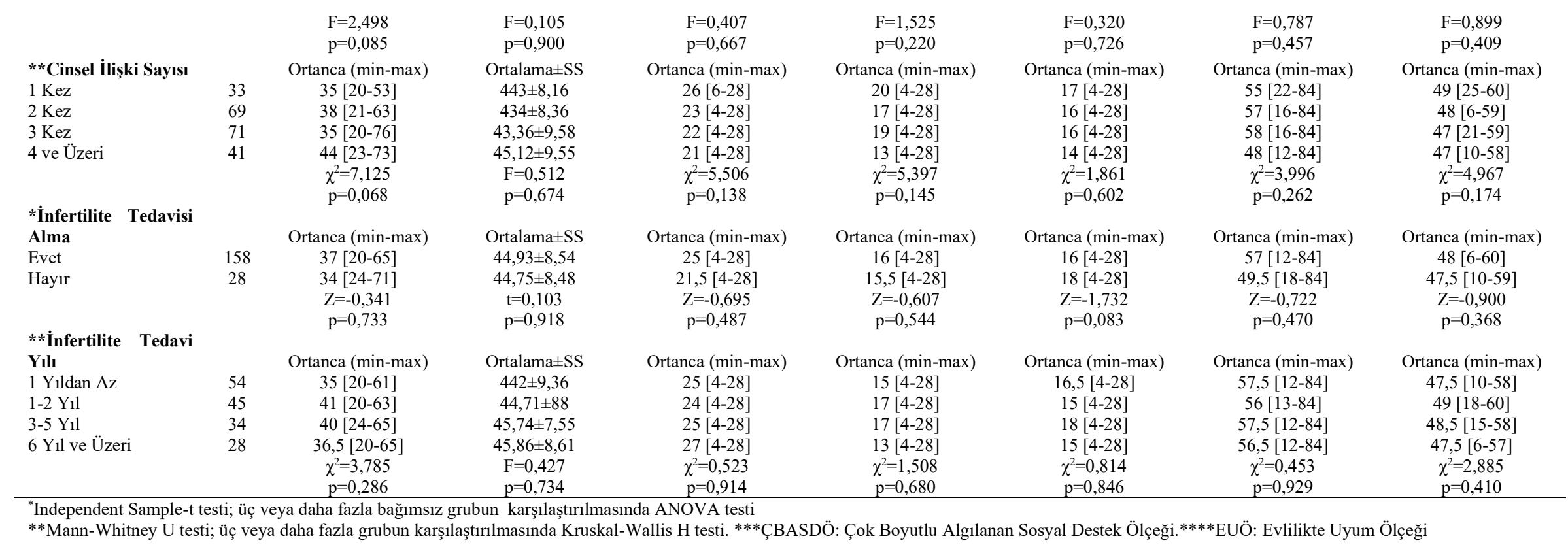


Soruların cevaplanma durumu değişkeni ile sürekli kaygı ölçeği toplam puan ortalamaları açısından istatistiksel olarak anlamlı farklılık tespit edilmiştir. Soruları tek başına cevaplayanların, sürekli kaygı ölçeği toplam puan ortalamaları, çift olarak cevaplayanlardan istatistiksel olarak anlamlı düzeyde daha yüksek bulunmuştur $(p=0,005)$. Katılımcıların, cinsiyet değişkenine göre sürekli kayg1 ölçeği toplam puan ortalamaları açısından istatistiksel olarak anlamlı farklılık tespit edilmiştir. Kadınların sürekli kaygı ölçeği toplam puan ortalamaları, erkeklerden istatistiksel olarak anlamlı düzeyde daha yüksek bulunmuştur $(p=0,000)$. Katılımcıların eğitim durumu değişkenine göre, sürekli kaygı ölçeği toplam puan ortalamaları açısından istatistiksel olarak anlamlı farklılık tespit edilmiştir. Üniversite ve üzeri mezun olanların sürekli kaygı ölçeği toplam puan ortalamaları, okuryazar olmayan ve lise mezunu olanlardan istatistiksel olarak anlamlı düzeyde daha düşük bulunmuştur $(p=0,019)$. Katılımcıların eğitim durumu değişkenine göre ÇBASDÖ toplam puan ortalamaları açısından istatistiksel olarak anlamlı farklılık tespit edilmiştir. Üniversite ve üzeri mezunu olanların ÇBASDÖ toplam puan ortalamalar1, okuryazar olmayan, ilkokul ve ortaokul mezunu olanlardan istatistiksel olarak anlamlı düzeyde daha yüksek bulunmuştur $(\mathrm{p}=0,000)$ (Tablo 3).

Katılımcıların, çalışma durumu değişkenine göre sürekli kaygı ölçeği toplam puan ortalamaları açısından istatistiksel olarak anlamlı farklılık tespit edilmiştir. Çalışmayan kişilerin sürekli kaygı ölçeğinden aldıkları toplam puan ortalamaları, çalışanlara göre istatistiksel olarak anlamlı düzeyde daha yüksektir $(\mathrm{p}=0,000)$. Katılımcıların çalışma durumu değişkenine göre ÇBASDÖ toplam puan ortalamaları açısından istatistiksel olarak anlamlı farklılık tespit edilmiştir. Çalışan kişilerin ÇBASDÖ toplam puan ortalamaları, çalışmayanlara göre istatistiksel olarak anlamlı düzeyde daha yüksektir $(p=0,041)$. Katılımcıların gelir düzeyi değişkenine göre durumluk ve sürekli kaygı ölçeği toplam puan ortalamaları açısından istatistiksel olarak anlamlı farklılık tespit edilmiştir. Geliri düşük olanların durumluk ve sürekli kaygı ölçeği toplam puan ortalamaları, orta ve yüksek olanlardan istatistiksel olarak anlamlı düzeyde daha yüksektir $(\mathrm{p}=0,030 ; \mathrm{p}=0,000)$. Katılımcıların gelir düzeyi değişkenine göre ÇBASDÖ toplam puan ortalamaları açısından istatistiksel olarak anlamlı farklılık tespit edilmiştir. Geliri düşük olanların ÇBASDÖ toplam puan ortalamaları, orta ve yüksek olanlara göre istatistiksel olarak anlamlı düzeyde daha düşüktür ( $\mathrm{p}=0,004)$ (Tablo 3).

İnfertil kadınların kronik hastalık varlığı değişkenine göre, durumluk kaygi ölçeği toplam puan ortalamaları açısından istatistiksel olarak anlamlı farklılık tespit edilmiştir. Kronik hastalığı olanların durumluk kaygı ölçeğinden aldıkları toplam puan ortalamaları, kronik hastalığ olmayanlara göre istatistiksel olarak anlaml düzeyde daha yüksek bulunmuştur $(p=0,003)$. İnfertil kadınların doğum kontrol yöntemi kullanma ve gebe kalma durumu değişkenlerine göre ÇBASDÖ toplam puan ortalamaları açısından istatistiksel olarak anlamlı farklılık tespit edilmiştir. Doğum kontrol yöntemi kullananların kullanmayanlara göre, gebe kalmayanların gebe kalanlara göre ÇBASDÖ aldıkları toplam puan ortalamaları istatistiksel olarak anlamlı düzeyde daha yüksek bulunmuştur $(\mathrm{p}=0,001)$. Katılımcıların kadın sağlığ 1 sorunu, infertilite nedeni, infertilite yılı, cinsel ilişki sayısı, infertilite tedavi alma durumu ve infertilite tedavi yılı değişkenlerine göre, durumluk ve sürekli kaygı ölçeği toplam puan ortalamaları, ÇBASDÖ toplam puan ortalamaları ve EUÖ toplam puan ortalamaları açısından istatistiksel olarak anlaml farklılı tespit edilmemiştir ( $p>0,05)$ (Tablo 4).

Katılımcıların durumluk kaygı ölçeği toplam puan ortalamaları 38,62 $\pm 11,64$, sürekli kaygı ölçeği toplam puan ortalamaları 43,51 18,96 ; ÇBASDÖ toplam puan ortalamaları $54,23 \pm 20,99$, ÇBASDÖ ait aile alt boyutu puan ortalaması $20,96 \pm 7,91$, arkadaş alt boyutu puan ortalaması $16,52 \pm 8,38$, özel kişi alt boyutu toplam puan ortalaması 16,74 $\pm 8,27$; EUÖ toplam puan ortalaması 46,42 $\pm 8,92$ olarak bulunmuştur (Tablo $5)$.

Tablo 5.Kaygı, ÇBASDÖ ve EUÖ Toplam Puan Ortalamalarının Dağılımı

\begin{tabular}{lcccc}
\hline Ölçek (N=261) & Ortalama \pm SS & Median & Min. & Max. \\
\hline *DKÖ & $38,62 \pm 11,64$ & 36 & 20 & 76 \\
*SKÖ & $43,51 \pm 8,96$ & 44 & 20 & 73 \\
*ÇBASDÖ & $54,23 \pm 20,99$ & 56 & 12 & 84
\end{tabular}




\begin{tabular}{|c|c|c|c|c|}
\hline Aile Alt Boyutu & $20,96 \pm 7,91$ & 25 & 4 & 28 \\
\hline Arkadaş Alt Boyutu & $16,52 \pm 8,38$ & 16 & 4 & 28 \\
\hline Özel Kişi Alt Boyutu & $16,74 \pm 8,27$ & 17 & 4 & 28 \\
\hline *EUÖ & $* * 46,42 \pm 8,92$ & 48 & 6 & 60 \\
\hline
\end{tabular}

S.S.= Standart sapma, *DKÖ: Durumluk Kaygı Ölçeği, *SKÖ: Sürekli Kaygı Ölçeği, *ÇBASDÖ: Çok Boyutlu Algılanan Sosyal Destek Ölçeği, *EUÖ: Evlilikte Uyum Ölçeği. **Katılımcıların \%75,5'i EUÖ toplam puan ortalaması 43 ve üzeridir.

$\mathrm{Bu}$ araştırmada, durumluk kaygı ölçeği ile sürekli kaygı ölçeği toplam puan ortalamaları arasında pozitif yönlü, zayıf derecede ve istatistiksel olarak anlamlı bir ilişki tespit edilmiştir. Durumluk kaygı ölçeği puanı arttıkça, sürekli kayg1 ölçeği puanı artmaktadır $\left(r_{s}=0,457, p=0,000\right)$. Araştırmada, sürekli kaygı ölçeği ile ÇBASDÖ ve EUÖ toplam puan ortalamaları arasında negatif yönlü, çok zayıf derecede ve istatistiksel olarak anlamlı bir ilişki tespit edilmiştir. Sürekli kaygı ölçeği puanı arttıkça, ÇBASDÖ ve EUÖ puanı azalmaktadir $\quad\left(r_{s}=-0,151, \quad p=0,014 ; \quad r_{s}=-0,223\right.$, $\mathrm{p}=0,000)$. Araştırmada durumluk kaygı ölçeği ile ÇBASDÖ ve EUÖ toplam puan ortalamaları arasında; ÇBASDÖ ile EUÖ arasında istatistiksel olarak anlamlı bir ilişki bulunmamıştır $(\mathrm{p}>05)$ (Tablo 6).

Tablo 6. İnfertil Bireylerin Durumluk-Sürekli Kaygı, ÇBASDÖ ve EUÖ Puan Ortalamaları Arasındaki İlișki

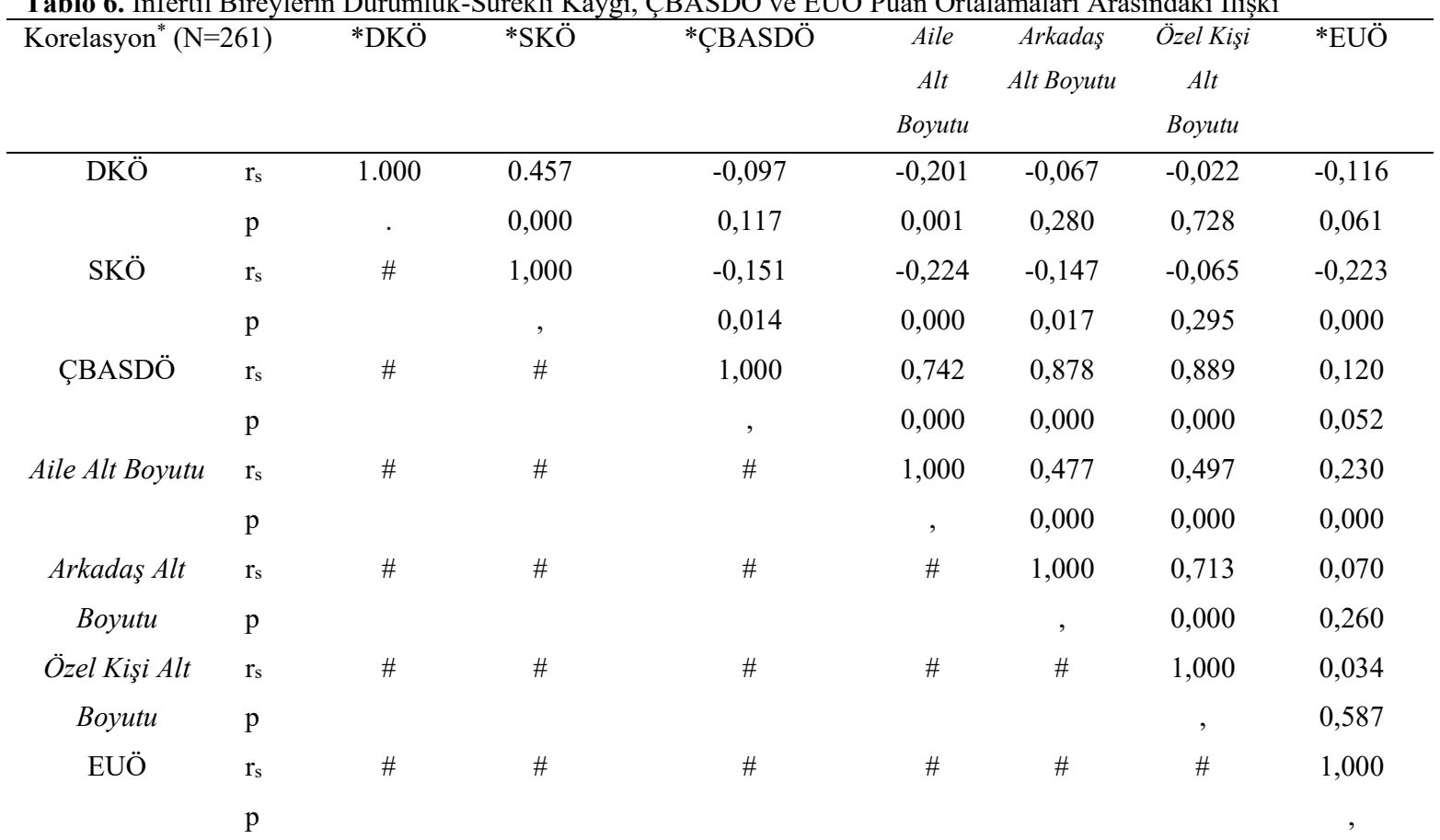

"Spearman korelasyon katsayısı, *DKÖ: Durumluk Kaygı Ölçeği, *SKÖ: Sürekli Kaygı Ölçeği, *ÇBASDÖ: Çok Boyutlu Algılanan Sosyal Destek Ölçeği, *EUÖ: Evlilikte Uyum Ölçeği

\section{TARTIŞMA}

İnertil bireylerin kaygı düzeylerinin, sosyal destek algilarının ve evlilik uyumlarının incelenmesi amacıyla yapılan bu araştırmadan elde edilen sonuçlarla, ülkemiz örnekleminde infertil bireylerin değerlendirilmesi ve yönlendirilmesine yönelik kapsamlı bilgi ortaya konması amaçlanmıştır.

Bireysel ve sosyo-demografik özellikler, infertilite kaynaklı fizyolojik ve psikososyal sorunların ortaya çıkmasında ve bireylerin infertiliteyi algılama biçimi üzerinde etkili olabilmektedir. Bu araştırmada, infertil kadınların yaş ortalaması $32,16 \pm 6,98$ bulunmuştur. 20'li veya 30'lu yaşlarındaki sağlıklı bir kadının gebelik şansı, herhangi bir adet döngüsünde yaklaşık \%2530 'dur. ${ }^{23,24}$ Kırk yaşına gelindiğinde, gebelik şansı \%10'un altına düşmektedir. $\mathrm{Bu}$ nedenle yaş infertilitede önemli bir faktördür. ${ }^{24}$ Türkiye Nüfus ve Sağlık Araştırması 2018 verilerine göre, 
ülkemizde en yüksek doğurganlık yaşının 25-29 yaşları arasında olduğu bildirilmiştir. ${ }^{25}$ Ülkemizde, infertil kadınlar arasında yapılan çalışmalarda kadınların yaş ortalamaları da çalışmamızla benzerlik göstermektedir. ${ }^{26,27}$ Günümüzde, kadınlarda gerek kariyer, gerekse ekonomik nedenlerden evlilik yaşının ilerlemesi doğurganlık yaşının da ilerlemesine neden olmaktadır.

$\mathrm{Bu}$ araştırmaya katılan infertil kadınların yaklaşık yarısının, BKİ puanına göre fazla kilolu (BKI > 250) sinıfinda oldukları bulunmuştur. Kadınların fertilite durumlarını etkileyen önemli faktörlerden biri de obezitedir. ${ }^{28,29}$ Jungheim ve ark., obez kadınların yardımcı üreme teknikleri ile gebe kalma oranlarının, obez olmayanlara oranla daha düşük olduğunu, gebe kaldıklarında da düşük yapma oranlarının arttığını belirtmiştir. ${ }^{28}$ Çünkü obezite, invitro fertilizasyon dahil olmak üzere infertilite tedavisine yönelik olumlu yanıt1 bozabilmektedir. ${ }^{30}$ Bireysel özellikler ve yaşam tarzı değişiklikleri infertilite sürecini etkilemektedir. ${ }^{1} \mathrm{Bu}$ nedenle infertilite tedavisi öncesinde ve tedavi süresince obeziteye yönelik danışmanlık yapılması, infertilite sürecine olumlu katkı sağlaması bakımından oldukça önemlidir.

$\mathrm{Bu}$ araştırmada, kadınların sürekli kayg1 düzeyleri erkeklerden daha yüksek bulunmuştur. Infertil çiftlerde, kadınların erkeklerden daha fazla stres yaşadığ 1 ve stresle başa çıkmada erkeklere göre daha çok başa çıkma yöntemi kullandıkları bilinmektedir. ${ }^{10,31}$ Altıntop ve Kesgin tarafindan yapılan araştırmada, kadınların durumluk kaygı ve sürekli kayg1 düzeylerinin erkeklere göre daha yüksek olduğu belirtilmiştir. ${ }^{32} \mathrm{Bu}$ sonuçların, kadın ve erkeklerin olumsuz etkilerle başa çıkmak için, sosyalleşmelerindeki farklılıklara bağlı olabileceği söylenebilmektedir.

Araştırmada, eğitim düzeyi üniversite ve üzeri olanların, eğitim düzeyi lise ve altı olanlara göre sürekli kayg1 düzeylerinin daha düşük ve sosyal destek algılarının daha yüksek olduğu bulunmuştur. İlerisoy tarafindan yapılan araştırmada, yüksek eğitim düzeyi ve meslek sahibi olmanın, infertil bireylerin baş etme mekanizmalarında öne çıktığı belirtilmiştir. İnfertil bireylerin, psikososyal sorunlarla baş etmede etkili birçok mekanizmalar bulunmaktadır. ${ }^{33}$ Eğitim düzeyinin yüksek olması, toplum tarafından infertil bireyler üzerinde kurulan baskıyla başa çıkabilmeleri açısından da oldukça önemlidir. Buna ek olarak, eğitim düzeyinin yükselmesi, bireylerin sosyal çevre edinmesini kolaylaştırmaktadır. ${ }^{34}$ İlerisoy tarafından yapılan araştırmada, eğitimli kadınların, infertilite deneyimlerini anlatırken, çocuksuz olmaktan daha çok yaşamlarının diğer alanlarına vurgu yaptıkları belirtilmiştir. ${ }^{33} \mathrm{Bu}$ durum eğitim durumu yüksek olanların sosyal desteği daha fazla önemsediğini göstermektedir. Ayrıca, eğitim ve meslek sahibi olmanın sosyoekonomik düzeyi olumlu etkilediği ve bu durumun infertil bireylerin çocuksuzluk sorunu ile baş etmelerinde önemli bir etken olabileceği düşünülmektedir.

Araştırmada, çalışanların sürekli kaygı düzeyi çalışmayanlardan daha düşük bulunmuştur. Altıntop ve Kesgin tarafindan yapılan araştırmada da, çalışan kişilerin çalışmayanlara göre sürekli kayg1 seviyesinin düşük olduğu belirtilmiştir. ${ }^{32} \mathrm{Bu}$ sonuçlar doğrultusunda infertil bireylerin, çalışma yaşamına bağlı olarak iş yoğunlukları nedeniyle kendilerini olumsuz düşüncelerden uzaklaştırdığg, benlik algısını ve özgüveni güçlendirdiği, bu nedenle infertilite stresiyle daha iyi başa çıkabildikleri söylenebilir.

$\mathrm{Bu}$ araştırmada, gelir düzeyi düşük olanların, gelir düzeyleri orta ve üstü olanlara göre durumluk/sürekli kaygı düzeyleri yüksek, sosyal destek algısı ise düşük olarak bulunmuştur. Altıntop ve Kesgin tarafindan yapılan araştırmada da çalışmamıza benzer bir şekilde, gelir düzeyleri düşük olanların durumluk/sürekli kaygı düzeylerinin daha yüksek olduğu belirtilmiştir. ${ }^{32}$ Tedavi masraflarının oldukça yüksek olması, gelir düzeyi düşük olan bireylerde kaygıyı arttırmaktadır. $\mathrm{Bu}$ doğrultuda bireylere sağlanan sosyal desteğin, bireylerin kaygı düzeyini azaltmada etkisi olacağ düşünülmektedir.

Araştırmaya katılan kadınlardan kronik hastalığı olanların, kronik hastalığı olmayanlara göre durumluk kaygı düzeyleri daha yüksek bulunmuştur. Literatürde, infertilite ile ilişkili değiştirilebilir faktörler arasında yer alan obezite, uzun vadeli sağlık sorunları ve bazı bulaşıcı hastalıkların infertilite tedavisinin başarısını olumsuz etkileyebileceği ve bu nedenle tedavi öncesi bu hastalıkların dışlanması gerektiği belirtilmektedir. ${ }^{35}$ Ayrıca, kadınlarda sadece obezitenin varlığ 1 bile diyabet, hiperlidemi, hipertansif hastalıklar, koroner kalp hastalıkları, inme, infarktüs, osteoartrit, endometriyal kanser, meme ve kolon kanseri gibi birçok kronik hastalıklara yol açmakla birlikte bunlara bağlı olarak üreme fonksiyonu sorunları ortaya çıkabilmektedir. ${ }^{29}$ Katılımcıların, kronik hastalıkları nedeniyle kaygılı olmaları, infertilite tedavisinin başarısını olumsuz etkileyeceğini düşünmelerinden kaynaklanabilir.

$\mathrm{Bu}$ araştırma kapsamındaki bireylerin, infertilite nedeni, infertilite yılı, infertilite tedavi alma durumu ve cinsel ilişki sıklığı değişkeni ile evlilik uyum ölçeği puan ortalaması arasında ilişki bulunmamıştır. Cetişli ve ark. tarafından yapılan çalışmada, infertilite süresi ile çift uyum ölçeği puan ortalamaları arasında, çalışmamızla benzer şekilde, ilişki bulunmamıştır. ${ }^{36}$ Literatürde, infertilite yılı için başlarda çiftlerin evlilik 
uyumlarının yüksek olduğu ancak, üç yıldan sonra evlilik uyumunun azaldığı belirtilmektedir. Ayrıca, infertilite sürelerinin uzaması, çiftlerin birbirlerini suçlamalarına, cinsel sorunlar yaşamalarına ve buna bağlı olarak ilişkilerinde uyumsuzluklara neden olabileceği bildirilmiştir. ${ }^{26,36-38}$ Tüzer ve ark. tarafından yapılan çalışmada, infertilite süresinin uzamasının ve erkek kaynaklı infertilitenin çift uyumunu etkilediği belirtilmiştir. ${ }^{39}$ Araştırmamızda, infertilite nedeni, infertilite yıll, infertilite tedavi alma durumu ve cinsel ilişki sıklığı değişkeninin evlilik uyumunu etkilememe nedeninin çalışmamızın örneklem sayısı ile ilişkili olduğu düşünülmektedir.

Araştırma kapsamındaki katılımcıların, sürekli kaygı düzeyleri arttıkça, sosyal destek algılarının ve evlilik uyumunun azaldığ bulunmuştur. Altıntop ve Kesgin tarafindan yapılan araştırmada, sosyal destek alma durumlarını yeterli görenlerin kaygı düzeylerinin düşük olduğu belirtilmiştir. ${ }^{32}$ İnfertil çiftlerde depresyon, anksiyete ve kaygı bozuklukları gibi psikolojik sorunların diğer çiftlere oranla daha fazla görüldüğü bildirilmektedir. ${ }^{12}$ Ancak, infertilitenin, çiftlerin uyumuna katkıda bulunup bulunmadığı henüz netlik kazanmamıştır. Bazı çalışmalar, infertilitenin evlilik uyumuna etkisinin olduğunu belirtirken, bazı çalışmalar ise duygusal anlamda bireylerin zorluklar yaşadığını ortaya koymuştur. ${ }^{14,16}$ Uzun süren tedavi süreci, ebeveynlik ve çocuksuzluğun kişinin hayatındaki önem verilme durumuna göre farklilık göstermektedir. ${ }^{16}$ İnfertil çiftler, sadece fiziksel olarak değil, psikososyal ve cinsel açıdan da değerlendirilmelidir. ${ }^{12} \quad$ Infertilite, çiftlerin hayatlarının çok önemli bir bölümünü etkilemektedir. ${ }^{40}$ Duman ve Koçak, infertil bireylerin durumlarını ilk olarak kendi aileleri ile paylaştıklarını belirtmiştir. Ailelerinin her durumda kendilerini koşulsuz sevdiklerini ve koşulsuz kabul gördüklerini düşünmeleri, çiftlerin infertilite problemleriyle baş etmelerinde önemli etken olduğu belirtilmektedir. ${ }^{12} \mathrm{Bu}$ durumun, yakın ailelerinin destek olacakları ve kendilerini damgalamayacaklarına duyulan güvenden kaynaklanabileceği düşünülmektedir.

Bireysel, sosyo-demografik, tıbbi ve obstetrik özellikler infertiliteye yol açmakta ya da infertilite tedavisinin başarısını olumsuz yönde etkileyebilmektedir. Bu nedenle, bireylere yaşam tarzı değişiklikleri konusunda evlilik öncesi ve sonrasında prekonsepsiyonel dönem danışmanlık hizmetlerinin verilmesi fertilitenin sürdürülmesinde oldukça önemlidir. Ayrıca sosyal desteğin, kaygı düzeyine olumlu yönde etkileri olduğu göz önüne alındığında, infertil bireylere verilecek danışmanlık hizmetinin yanında, bireylerin yakın çevresinin de sürece dahil edilmesi, infertilitenin yol açtığı sorunlarla baş etmede bireylere ek destek sağlayabilir.

\section{Araştırmanın Sınırlılıkları}

Araştırmanın bazı sınırlılıkları bulunmaktadır. Bu araştırmaya katılan bireylerin büyük çoğunluğu tedavi gören bireylerdir. Bu durum tedavi sürecinin etkisi ile infertilitenin etkilerini ayırt edebilmeyi güçleştirmektedir. Bulgular tüm infertil bireyler için genellenemez. İnfertilite tedavisi için başvuran bireyler sadece ilk başvurulara çift olarak geldiklerinden araştırmaya katılan erkek birey sayısı daha azdır. Okuma yazma bilmeyen bireylerle, mahremiyetin sağlandığı bir odada araştırmacı tarafından yüz yüze görüşmeyle formlar doldurulduğu için bireyler gerçek duygularını yansıtmamış olabilirler.

\section{SONUÇ}

Sonuç olarak, ölçeklerden elde edilen puan ortalamalarına göre katılımcılar orta düzeyde kaygılı, orta düzeyin üzerinde sosyal destek algısına sahip ve EUÖ toplam puan ortalamalarına göre \%75,5'nin evlilikleri uyumlu olarak bulunmuştur. Ölçekler arası ilişkiye bakıldığında, durumluk kaygı ölçeği puanı arttıkça, sürekli kaygı ölçeği puanının arttığı, sürekli kaygı ölçeği puanı arttıkça, ÇBASD ölçeği ve evlilik uyum ölçeği puanının azaldığı saptanmıştır. Sosyo-demografik değişkenler, kayg1 düzeyi ve sosyal destek algılarıyla ilişkili bulunmuştur. Kadın katılımcıların sürekli kayg1 düzeyleri, erkeklerden daha yüksektir. Katılımcıların gelir getiren bir işte çalışmaları, eğitim ve gelir düzeylerinin yüksek olması, kaygı düzeylerini azaltmakta, sosyal destek algılarını ise arttırmaktadır. Bireylerin kaygı düzeyleri arttıkça, sosyal destek algısı ve evlilik uyumları azalmaktadır. $\mathrm{Bu}$ araştırma sonuçlarının, üreme sağlığ1 hizmetlerinde yer alan tüm sağlık profesyonellerine, infertil bireylere nitelikli ve etkin danışmanlık hizmeti sunulabilmesi için yol gösterici olabileceği düşünülmektedir.

\section{Çıkar çatışması}

Yazarlar arasında çıkar çatışması yoktur.

\section{Teşekkür}

Çalışmaya katılan tüm katılımcılara teşekkür ederiz.

\section{KAYNAKLAR}

1. Yılmaz F, Yardımcı H. Beden Kütle İndeksinin infertilite üzerine etkisi. Hacettepe Üniversitesi Sağlık Bilimleri Fakültesi Dergisi 2015;1 (1):1-6.

2. Wiweko B, Anggraheni U, Elvira SD, Lubis, HP. Distribution of stress level 
among infertility patients. Middle East Fertility Society Journal 2017; 22(2): 145148. DOI:10.1016/j.mefs.2017.01.005.

3. Zegers-Hochschild F, Adamson, GD, Dyer S, Racowsky C, De Mouzon J, SokolR,et al. The international glossary on infertility and fertility care. Human Reproduction 2017;32(9): 1786-1801. DOI:10.1093/humrep/dex234.

4. ACOG (American College of Obstetricians and Gynecologist). Infertility Workup for the Women's Health Specialist: Acommittee opinion 781 . İnfertility workup 2019; 133(6): 377-382. https://www.acog.org/-

/media/project/acog/acogorg/clinical/files/ committee-

opinion/articles/2019/06/infertility-

workup-for-the-womens-health-

specialist.pdf. Erişim:01.02.2020.

5. Karaca A, Ünsal G, İnfertilitenin kadın ruh sağlığı üzerine etkileri ve psikiyatri hemşiresinin rolü. Psikiyatri Hemşireliği Dergisi 2012; 3(2):80-85. DOI:10,5505/phd,2012,02486.

6. Gürbüz AS, Özçimen EE, editörler. Temel jinekoloji ve obstetri. 1. Bask1. İstanbul: Nobel Tıp Kitabevi;2021.p.113.

7. Diamond RM. Infertility and Pregnancy loss in couple and family therapy. Encyclopedia of Couple and Family Therapy 2019: 1475-1479. DOI:10.1007/978-3-319-49425-8.

8. The National Infertility Organization .What is infertility? 2016. http://www.resolve. org/aboutinfertility/what-isinfertility/.Erişim:19.02.2020.

9. Zegers-Hochschild F, Adamson GD, De Mouzon J, Ishihara O, Mansour R, Nygren $\mathrm{K}$, et al. The international committee for monitoring assisted reproductive technology (ICMART) and the World Health Organization (WHO) revisedglossary on ART terminology. Fertility and Sterility 2009; 92(5):15201524. DOI:10.1093/humrep/dep368.

10. Yılmaz T, Oskay ÜY. İnfertilite stresi ile başa çıkma yöntemleri ve hemşirelik yaklaşımları. Sağlık Bilimleri ve Meslekleri Dergisi 2015;2(1): 100-112.

11. Wischmann T, Kentenich H. A couple who cannot conceive: Coping with infertility. In Bio-Psycho-Social Obstetrics and Gynecology 2017; 249-261. DOI:10.1007/978-3-319-40404-2 14.

12. Duman NB, Koçak DY. İnfertilitenin cinsel sağlığa etkileri ve profesyonel hemşirelik yaklaşımları. Türkiye Klinikleri Obstetric-Women's Health and Diseases Nursing-Special Topics 2016;2(1): 51-8.

13. Chaves C, Canavarro M C, Moura-Ramos M. The role of dyadic coping on the marital and emotional adjustment of couples with infertility. Family Process 2019; 58(2): 509-523. DOI:10.1111/famp.12364.

14. Pasch LA, Sullivan KT. Stress and coping in couples facing infertility. Current opinion in psychology 2017;13: 131-135. DOI:10.1016/j.copsyc.2016.07.004.

15. Luk BHK, Loke AY. The impact of infertility on the psychological well-being, marital relationships, sexual relationships, and quality of life of couples: A systematic review. Journal of sex\&marital therapy 2015;41(6): 610-625. DOI:10.1080/0092623X.2014.958789.

16. Moura-Ramos M, Gameiro S, Canavarro MC, Soares I, Almeida-Santos T. Does infertility history affect the emotional adjustment of couples undergoing assisted reproduction? The mediating role of the importance of parenthood. British Journal of Health Psychology 2016;21(2): 302317.DOI:10.1111/bjhp.12169.

17. Bodur NE, Çoşar B, Erdem M. İnfertil çiftlerde evlilik uyumunun demografik ve klinik değişkenlerle ilișkisi. Cukurova Medical Journal 2013;38(1): 51-62.

18. Read SC, Carrier ME, Boucher ME, Whitley R, Bond S, Zelkowitz P. Psychosocial services for couples in infertility treatment: What do couples really want? Patient Education and Counseling 2014;94(3): 390-395. DOI:10.1016/j.pec.2013.10.025.

19. Luk BHK, Loke AY. A review of supportive intervention stargeting individual sorcouples undergoing infertility treatment: Directions for the development of interventions. Journal of sex\&marital therapy 2016;42(6): 515-533. DOI:10.1080/0092623X.2015.1074133.

20. Öner N ,Le Compte A, editörler. Durumluk Sürekli Kaygı Envanteri El 
Kitab1. 1. Bask1. İstanbul: Boğaziçi Üniversitesi Yayınlar1;1983.p.1-26.

21. Eker D, Arkar H, Yaldız H. Çok boyutlu algılanan sosyal destek ölçeğinin gözden geçirilmiş formunun faktör yapısı, geçerlik ve güvenirliği. Türk Psikiyatri Dergisi 2001;12(1):17-25.

22. Tutarel Kışlak Ş. Evlilikte uyum ölçeğinin güvenirlik ve geçerlik çalışması. 3P Dergisi 1999; 7(1):50-56.

23. Practice Committee of American Society for Reproductive Medicine. Diagnostic evaluation of the infertile female: a committee opinion. Fertil Steril 2012;98(2):302-7.

DOI:10.1016/j.fertnstert.2015.03.019.

24. ACOG (American College of Obstetricians and Gynecologists). Treating Infertility. 2017. https://www.acog.org/patientresources/faqs/gynecologicproblems/treating-infertility. Erişim:20.02.2020.

25. Türkiye Nüfus ve Sağlı Araştırması (TNSA). Hacettepe Üniversitesi Nüfus Etütleri Enstitüsü. TÜBİTAK, Ankara, Kasım,

2018.http://www.hips.hacettepe.edu.tr/tnsa 2018/rapor/TNSA2018_ana_Rapor.pdf

.Erişim:20.02.2020.

26. Güleç G, Hassa H, Yalçın EG, Yenilmez Ç. Tedaviye başvuran infertil çiftlerde, infertilitenin cinsel işlev ve çift uyumuna etkisinin değerlendirilmesi. Türk Psikiyatri 2011;22(3):166-76. DOI: 10.5080 $\mathrm{U} 6362$.

27. Keskin G, Babacan Gümüş A. İnfertilite: umutsuzluk perspektifinden bir inceleme. Psikiyatri Hemşireliği Dergisi 2014;5(1):9-16.DOI:

10.5505/phd.2014.07269.

28. Jungheim ES, Travieso JL, Hopeman MM. Weighing the impact of obesity on female reproductive function and fertility. Nutrition Reviews 2013; 71(1): 3-8. DOI:10.1111/nure.12056.

29. Yanıkkerem E. Obezitenin kadın sağlığına etkileri. Kocaeli Üniversitesi Sağlık Bilimleri Dergisi 2017;3(1): 37-43. DOI:10.30934/kusbed.359281.
30. Lindsay TJ, Vitrikas KR. Evaluation and treatment of infertility. American family physician 2015;91(5): 308-314.

31. Haica CC. Gender differences in quality of life, intensity of dys functional attitudes, unconditional self-acceptance, emotional distress and dyadic adjustment of infertile couples. Procedia-Social and Behavioral Sciences 2013; 78: 506510.DOI:10.1016/j.sbspro.2013.04.340.

32. Altıntop İ, Kesgin B. İnfertilite tedavisi gören çiftlerin kayg1, psikolojik dayanıklılık düzeyleri ile başa çıkma stratejileri. Journal of International Social Research 2018; 11(55):755-768 DOI:10.17719/jisr.20185537247.

33. İlerisoy M. İnfertilite tedavisi gören bireylerin duygusal yaşantıları ve baş etme yöntemleri üzerine bir araştırma. İstanbul Ticaret Üniversitesi Sosyal Bilimler Dergisi 2015;14(28):143-164.

34. Hammerli K, Znoj H, Berger T. Internetbased support for infertile patients: A randomized controlled study. Journal of Behavioral Medicine 2010; 33(2): 135-46. DOI:10.1007/s10865-009-9243-2.

35. Kutlu R, Işıklar Özberk D, Görkemli H. Infertil kadınlarda metabolik sendrom ve uzun dönem kronik sağlık sorunları sıklığı. İstanbul Med 2017; 18(4): 210-7.DOI: 10.5152/imj.2017.55823.

36. Cetişli NE, Ören EDT, Kaba F. İnfertil çiftlerde çift uyumu ve umutsuzluk. Acıbadem Üniversitesi Sağlık Bilimleri Dergisi 2018;81:1-5.

37. Sezgin H, Hocaoğlu Ç. İnfertilitenin psikiyatrik yönü. Psikiyatride Güncel Yaklaşımlar 2014;6(2):165-84. DOI: $10.5455 /$ cap. 20131001091415.

38. Zeren F, Gürsoy E. İnfertil Çiftlerde Çift Uyumu ve Yaşam Kalitesinin Önemi. Koç Üniversitesi Hemşirelikte Eğitim ve Araştırma Dergisi (HEAD) 2019; 16(1): 68-72.DOI:10.5222/HEAD.2019.068.

39. Tüzer V, Tuncel A, Göka S, Bulut SD, Yüksel FV, Atan A, et al. Marital adjustment and emotional symptoms in infertile couples: gender differences. Turkish Journal of Medical Sciences 2010;40 (2) :229-37.DOI:10.3906/sag0901-17. 
40. Ferreira M, Antunes L, Duarte J, Chaves C. Influence of infertility and fertility adjustment on marital satisfaction.
Procedia-Socialand Behavioral Sciences

2015; 171:

103.DOI:10.1016/j.sbspro.2015.01.094. 